\title{
A 25-Year Experience with a Project-Centered Master in Public Health: Key to Public Health Relevance and Educational Efficacy?
}

\author{
Philippe Chastonay1, Emilien Jeannot ${ }^{2}$, Beat Stoll2, Thomas Mattige,3, Roberto Moretti2,4, \\ Florence Walker ${ }^{2}$, Emmanuel K. Mpinga ${ }^{2 *}$ \\ ${ }^{1}$ Public Health Schweiz, Bern, Switzerland \\ ${ }^{2}$ Institute Global Health, Faculty of Medicine, University of Geneva, Geneva, Switzerland \\ ${ }^{3}$ Swiss Health Promotion Foundation, Bern, Switzerland \\ ${ }^{4}$ Health Promotion Service ASL of Bergamo, Bergamo, Italy \\ Email: *emmanuel.kabengele@unige.ch
}

How to cite this paper: Chastonay, P., Jeannot, E., Stoll, B., Mattig, T., Moretti, R., Walker, F., \& Mpinga, E. K. (2017). A 25Year Experience with a Project-Centered Master in Public Health: Key to Public Health Relevance and Educational Efficacy? Creative Education, 8, 461-470.

https://doi.org/10.4236/ce.2017.83035

Received: December 15, 2016

Accepted: March 28, 2017

Published: March 31, 2017

Copyright $\odot 2017$ by authors and Scientific Research Publishing Inc. This work is licensed under the Creative Commons Attribution International License (CC BY 4.0).

http://creativecommons.org/licenses/by/4.0/

\begin{abstract}
The World Health Organization has recognized the shortage of competent public health workforce as a major problem worldwide and claimed an urgent need for action. Training public health personnel, effective in an educational perspective, yet with public health relevance in mind, remains a challenge for university-based programs. We present evaluation data of the 25-year experience of a project-centered, problem-oriented, on-job Master in Public Health program at the University of Geneva. Several data collection strategies were used. First, achievement of learning objectives was investigated through content analysis of students' reports on personal project, through problemsolving final examinations and through self-reported progress on a professional profile. Second, possible public health impact was estimated through analysis of implemented project. Third, yearly discussions with the successive cohorts use the SWOT grid (strengths, weaknesses, opportunities and threats) to investigate the students' perception of the program. Learning objectives were mainly acquired through community health projects realization, partly also through group work, exercises, readings and lectures. Self-reported progress on a professional profile showed significant acquisitions in all tested public health competencies. All students were able to implement at least one of their planned projects. Students' perception considered the project/problem-centered approach as positive, but underlined the importance of time constraints and heavy workload in an on-job training program. In our experience a project-centered, problem-based Master program in Public Health allowed students to achieve new competencies and communities to benefit from project implementation addressing public health issues.
\end{abstract}




\section{Keywords}

Public Health Training, Project-Based Learning, Problem-Based Learning, Problem-Solving, Public Health Competencies, Evaluation

\section{Introduction}

The shortage of a competent public health workforce has been recognized as a major problem by the World Health Assembly. WHO has claimed an urgent need for action (WHO, 2007). One of the well-identified causes of such deficient public health competencies is the lack of adequate training, i.e. training that takes into account the health needs of the population (WHO, 2006; HRSA, 2005) as well as training that integrates effective educational strategies (Guilbert, 1999; Pruitt \& Epping-Jordan, 2005). Indeed, educational experts have stressed that relevancy of a public health training program, i.e. its capacity to address priority health needs of the population, is a key factor to any training program aiming at having some impact on public health problems the communities are facing (Institute of Medicine of the National Academies, 2003; Petrakova \& Sadana, 2007), university-based programs often being excessively academically-oriented (EU Education and Culture DG, 2015).

In the late 1980s a study of the University of Geneva exploring the needs for competencies in the public health sector in French-speaking Switzerland (Chastonay, Guilbert, \& Rougemont, 1992) concluded that it was imperative to develop an on-job public health training program of master's level that would be fully community-oriented adopting a partially community-project-based learning strategy (Chastonay, Durieux-Paillard, Guilbert et al., 1994), thus respecting the recommendations of modern andragogy (Knowles, Holton, \& Swanson, 2015), as well as possibly impacting concrete public health outcomes (Jacobs, Jones, Gabella et al., 2012). The development of such a program was at that time possible due to the policy of the Swiss Federal Government allocating extra funding to promote continuing education, the concept behind being "to promote acquisition of new professional competencies and to favor job-mobility" in a rapid changing work environment, a policy still in force (CH-EDK, 2013). Universities were eligible to such funding.

We present some evaluation data of the 25 years experience of a Master in Public Health program at the University of Geneva, an on-job program heavily project-centered and problem-oriented and discuss some successes, challenges, limitations and failures of such a program.

\section{Methods}

\subsection{Brief Description of the Program}

The Geneva University Master Program in Public Health (Master of Advanced Studies in Public Health according to the Bologna Protocol (European Commission (2015) is an on job part-time three-year public health training program. 
Students are mostly mid-level health professionals working either in health care or in public health institutions (physicians, nurses, mid-wives, economists, biologists, sociologists, lawyers, etc.) from French-speaking Switzerland and nearby France and Italy with up to $20 \%$ of students from French-speaking African countries. Classes are limited to 5 - 15 students a year (Chastonay, DurieuxPaillard, Guilbert et al., 1994). The program is heavily based on the development and implementation of public health projects relevant to the students' employers/communities and on problem-solving case studies in-group work. More traditional teaching like lectures are limited to basic public health topics/disciplines/methods. Special attention is given to "sharing" the individual experience and expertise of and with students (Chastonay, Papart, Durieux- Paillard, 1997).

\subsection{Evaluation Procedures}

\subsubsection{Target Population}

The target population was the graduates of 25 successive cohorts of students from the beginning of the program in 1990 to present (n: 166 graduates). As mentioned above the students are mostly mid-level health professionals with at least 5 years of professional experience working either in health care or in public health institutions (physicians, nurses, mid-wives, economists, biologists, sociologists, lawyers, etc.). The male/female ratio is 0.9 . The age range was 26 - 51 years, with a mean age of 37 years.

\subsubsection{Evaluation}

First, achievement of learning objectives was investigated through content analysis of students' reports on personal projects in relation to pre-defined learning objectives (Hsieh \& Shannon, 2005), through problem-solving final examinations and on a self-reported progress on a professional profile, profile defined during the planning phase of the program on the basis of international recommendations and local studies among senior public health professionals and state medical officers (Chastonay, Guilbert, \& Rougemont, 1992; Public Health Foundation, 2010). Second, possible public health impact was estimated through implemented project analysis (Habicht, Victora, \& Vaughan, 1999). Third, yearly satisfaction inquiries were done with the successive cohorts using the SWOT grid (strengths, weaknesses, opportunities and threats) (Sorensen \& Vidal, 1999) to investigate the students' perception of the program: the SWOT grid method implies that students list the main strengths and weaknesses of the program, as well opportunities and threats the program faces on the long run. The listing was completed individually and later discussed among members of the respective cohorts.

\section{Results}

\subsection{Learning Evaluation}

Examples of learning objectives in the context of developed public health projects by students are given in Table 1 . The project implementation allowed achieving learning objectives while having some community impact.

Examples of certifying exams are given in Table 2, indirectly illustrating the 
Table 1. Learning evaluation: Examples learning objectives for given students through project planning and implementation in order to solve a "real-life" problem.

\begin{tabular}{|c|c|c|c|c|}
\hline \multicolumn{5}{|c|}{ Project 1 : Study investigating collaboration needs between a hospital emergency ward and general practioners in an inner city (DB 93) } \\
\hline Identified problem & $\begin{array}{l}\text { Training objectives } \\
\text { for the student }\end{array}$ & $\begin{array}{l}\text { Newly acquired } \\
\text { knowledge and } \\
\text { competencies } \\
\text { (not exhaustive) }\end{array}$ & $\begin{array}{l}\text { Established } \\
\text { collaboration } \\
\text { through the project }\end{array}$ & $\begin{array}{c}\text { Short-term } \\
\text { socio-sanitary } \\
\text { impact of the project }\end{array}$ \\
\hline $\begin{array}{l}\text { Non optimal care of } \\
\text { emergency ward patients } \\
\text { (due to lack of medical } \\
\text { information available } \\
\text { on admission) }\end{array}$ & $\begin{array}{l}\text { Develop a needs assesment } \\
\text { study clarifying the } \\
\text { collaboration needs } \\
\text { between emergency ward } \\
\text { health personnel and } \\
\text { general practionners }\end{array}$ & $\begin{array}{l}\text { Role of a health care } \\
\text { service in the community } \\
\text { development of a } \\
\text { questionnaire } \\
\text { consensus techniques } \\
\text { concept of "emergency" }\end{array}$ & $\begin{array}{l}\text { Top management } \\
\text { of the hospital } \\
\text { emergency service } \\
\text { general practitioner } \\
\text { patient associations } \\
\text { social workers }\end{array}$ & $\begin{array}{l}\text { Implementation of a pilot } \\
\text { project of collaboration } \\
\text { between general } \\
\text { practitioners and the local } \\
\text { Hospital Emercency Service }\end{array}$ \\
\hline \multicolumn{5}{|c|}{$\begin{array}{l}\text { Project } 2 \text { Development of an informatic Epi-Info course for public health field workers } \\
\text { as a support to the epidemic surveillance at district level (RM 95) }\end{array}$} \\
\hline Identified problem & $\begin{array}{l}\text { Training objectives } \\
\text { for the student }\end{array}$ & $\begin{array}{c}\text { Newly acquired } \\
\text { knowledge and } \\
\text { competencies (not exhaustive) }\end{array}$ & $\begin{array}{l}\text { Established collaboration } \\
\text { through the project }\end{array}$ & $\begin{array}{c}\text { Short-term } \\
\text { socio-sanitary } \\
\text { impact of the project }\end{array}$ \\
\hline $\begin{array}{l}\text { Lack of motivation of field } \\
\text { public health officers in } \\
\text { collecting infections } \\
\text { disease data due to } \\
\text { disconfort in using } \\
\text { specific computer software }\end{array}$ & $\begin{array}{l}\text { Plan an introductive } \\
\text { Epi-Info software course } \\
\text { for field public health } \\
\text { officers in order to help } \\
\text { them develop an infectious } \\
\text { disease surveillance system }\end{array}$ & $\begin{array}{l}\text { Basic concept } \\
\text { epidemiological surveillance } \\
\text { principles of andragogy } \\
\text { communication strategies } \\
\text { use of the Epi-Info software }\end{array}$ & $\begin{array}{l}\text { Public health authorities } \\
\text { public health } \\
\text { surveillance experts } \\
\text { general practitioners }\end{array}$ & $\begin{array}{c}\text { Implementation of a } \\
\text { epidemiological } \\
\text { surveillance system of } \\
\text { infectious disease ast a } \\
\text { regional level }\end{array}$ \\
\hline
\end{tabular}

Table 2. Learning evaluation: examples of certifying exams at the end of the program (72-hour group work).

\section{Assignement}

Elaborate a plan allowing a 200-bed acute care hospital to get the WHO label "Children friendly hospital"

List arguments for the state health minister in favor/disfavor of systematic vaccination against Hepatitis B Virus of teen-agers

Elaborate a health prevention plan for the State Health Officer establishing the strategy, objectives, activities and evaluation mechanisms in case of a future heat-wave

Develop a flyer for the state health authorities informing the population of the advantages of getting vaccinated against seasonal influenza virus

Compare the strengths and weaknesses of the health systems of 3 different European countries

List arguments for the state health minister in favor/disfavor of establishing a «Stroke Unit » at the State hospital

Develop a communication strategy towards parents regarding the usefulness of a HPV vaccination program targeting teen-age girls

Organize a fictive press conference on the potential benefits and dangers of recommending the introduction of low-doses of "aspirin" into drinking water as a global prevention strategy

kind of competencies students had to acquire during the curriculum, i.e. practical public health competencies.

Table 3 illustrates the self-perceived progress in various public health competencies (professional profile) achieved by the end of the program by 5 consecutive cohorts: globally progress is achieved, yet at various levels depending the specific tasks. For example, at the beginning of their curriculum only $16.6 \%$ of students considered themselves competent or highly competent for the specific task "Establish the health profile of the population at local and national levels"; 
by the end the percentage was up to $75 \%$. Best acquired competencies as stated by $91.6 \%$ were "Communicate with the population, with health authorities, with NGOs", "Collaborate with health professionals and coordinate common actions", "Develop, implement and evaluate training programs for health professionals". Less acquired competencies included "Organize an information system to collect health data" (62.5\%) and "Analyze the financial impact of health promotion programs"(58.3\%).

\subsection{Impact Evaluation}

Institutional and community impacts may be linked to the implementation of specific projects by students. Table 4 gives some examples of projects developed and implemented during the training by students and it shows the estimated related impact either at the institutional level or at community level. Each student eventually implemented at least one project over his training time, often small grass-root projects limited to a specific setting, but sometimes also quite large projects as shown in Table 4.

\subsection{Satisfaction Evaluation}

Satisfaction evaluation allowed identifying strengths and weaknesses of the program

Table 3. Degree of self-perceived competency in public health tasks at the beginning and at the end of the program (5 consecutive cohorts n: 48) (on a 4-point scale 1 no competency, 2 basic competency, 3 competent, 4 highly competent).

\begin{tabular}{|c|c|c|c|}
\hline Public Health Competencies of a public health professional & $\begin{array}{l}\text { At the beginning } \\
\% \text { of students claiming } \\
\text { levels of competency } \\
3 \text { or } 4\end{array}$ & $\begin{array}{c}\text { At the end } \\
\% \text { of students claiming } \\
\text { levels of competency } \\
\text { 3or } 4\end{array}$ & $P$ \\
\hline \multicolumn{4}{|l|}{ Implement health prevention and health promotion activities } \\
\hline -Develop health prevention and promotion strategies and action plans & 37.5 & 83.3 & $<0.001$ \\
\hline -Implement health prevention and promotion programs & 33.3 & 79.1 & $<0.001$ \\
\hline -Support at the technical level health authorities & 41.6 & 87.5 & $<0.001$ \\
\hline \multicolumn{4}{|l|}{ Collaborate and communicate } \\
\hline -Communicate with the population, with health authorities, with NGOs & 50.0 & 91.6 & $<0.001$ \\
\hline -Collaborate with health professionals and coordinate common actions & 50.0 & 91.6 & $<0.001$ \\
\hline -Council health authorities on the health of the population & 45.8 & 79.1 & $<0.001$ \\
\hline \multicolumn{4}{|l|}{ Manage public health activities and structures } \\
\hline -Identify health priorities according to urgency and economic constraints & 25.0 & 70.8 & $<0.001$ \\
\hline -Prepare public health projects including budget and legal aspects & 20.8 & 79.1 & $<0.001$ \\
\hline -Analyze and formulate public health objectives (at local and national levels) & 33.3 & 87.5 & $<0.001$ \\
\hline -Plan and manage health workforce development including life-long training & 20.8 & 66.6 & $<0.001$ \\
\hline \multicolumn{4}{|l|}{ Develop and implement research activities } \\
\hline -Establish the health profile of the population at local and national levels & 16.6 & 75.0 & $<0.001$ \\
\hline -Organize an information system to collect health data & 12.5 & 62.5 & $<0.001$ \\
\hline -Analyze the financial impact of health promotion programs & 8.3 & 58.3 & $<0.001$ \\
\hline -Evaluate the efficacy/efficiency of public health programs & 8.3 & 70.8 & $<0.001$ \\
\hline -Design a public health research project & 20.8 & 75.0 & $<0.001$ \\
\hline \multicolumn{4}{|l|}{ Train health personal } \\
\hline -Develop, implement and evaluate training programs for health professionals & 54.1 & 91.6 & $<0.001$ \\
\hline \multicolumn{4}{|l|}{ Self-evaluation } \\
\hline -Evaluate one's activities in order to better perform & 41.6 & 83.3 & $<0.001$ \\
\hline
\end{tabular}


Table 4. Impact evaluation: Examples of projects implemented by students and estimated/observed results on institutional or community levels.

\begin{tabular}{|c|c|}
\hline Projects & Estimated/Observed Result \\
\hline $\begin{array}{l}\text { Planning of a breast cancer screening } \\
\text { (mammography) program at state level }\end{array}$ & $\begin{array}{l}\text { Implementation of the breast cancer screening program at a state level } \\
\qquad(\text { Swiss canton with a population of } 400,000)\end{array}$ \\
\hline $\begin{array}{l}\text { Planning of a participative nosocomial infection } \\
\text { prevention program in a neonatal hospital unit }\end{array}$ & $\begin{array}{l}\text { Implementation of a nosocomial infection prevention } \\
\text { program at a University Hospital }\end{array}$ \\
\hline $\begin{array}{l}\text { Development of a model for rationalizing } \\
\text { the purchase of hospital material at a regional level }\end{array}$ & $\begin{array}{l}\text { Implementation of the model by the regional network of hospitals } \\
\text { (including } 3 \text { regional acute hospitals of approximately a total of } 600 \text { beds) }\end{array}$ \\
\hline $\begin{array}{l}\text { Analysis of the situation of school health at a state level } \\
\text { and recommendations for change }\end{array}$ & $\begin{array}{l}\text { Implementation of a new concept of school health at a state level } \\
\text { (Swiss canton with a population of } 750,000)\end{array}$ \\
\hline Planning of a "Smoke-free Hospital" campaign & $\begin{array}{l}\text { Implementation of the campaign and obtaining the WHO } \\
\text { Smoke-free-Hospital Label at a chronic disease hospital }\end{array}$ \\
\hline $\begin{array}{l}\text { Conception and development of a cartoon } \\
\text { booklet on caries prevention among children }\end{array}$ & $\begin{array}{l}\text { Use of the booklet in several caries prevention programs in two } \\
\text { different countries at local/regional levels (Cameroon and Morocco) }\end{array}$ \\
\hline $\begin{array}{l}\text { Study on the high decibel levels } \\
\text { in nightclubs at state level }\end{array}$ & $\begin{array}{l}\text { Adoption of a state law limiting Db levels in nightclubs } \\
\quad(\text { Swiss canton with a population of } 380,000)\end{array}$ \\
\hline $\begin{array}{l}\text { Public health project planning-a computer-based } \\
\text { manual for community health professionals }\end{array}$ & $\begin{array}{c}\text { Use of the tool at daily basis by field health professionals } \\
\text { of several Health Promoting Associations at a state level } \\
\text { (Swiss canton with a population of } 750,000)\end{array}$ \\
\hline $\begin{array}{l}\text { Need assessment and feasibility study for a continuing } \\
\text { public health training program for pharmacy practitioners }\end{array}$ & $\begin{array}{l}\text { Implementation of a Community Health curriculum } \\
\text { for pharmacy practitioners }\end{array}$ \\
\hline $\begin{array}{l}\text { Development of an educational CD and Website on } \\
\text { "Health and Human rights" }\end{array}$ & $\begin{array}{l}\text { Implementation of a Certificate of Advanced Studies on } \\
\text { "Discriminations, Health and Human Rights" that has been running } \\
\text { for several years, notably at distance in } 6 \text { francophone African countries }\end{array}$ \\
\hline
\end{tabular}

as perceived by the students. Table 5 shows overall perception of students when data of successive years were aggregated. "Group dynamics" appears as a strong point, as well as "student-colleagues' public health expertise". "Networking" and "community-project conception/implementation" are other strong elements of the program. Weaknesses put forward are namely "limited interaction with students' employers" and "little visibility of the program at national and international levels". Interesting named potentials are "intercultural exchanges among students from different cultural backgrounds" and "multi-professional classes". Obstacles mentioned are "time constraints" or "additional workload".

\section{Discussion}

Our program has adopted the main principles of andragogy (Knowles, Holton, \& Swanson, 2015), therefore being very problem-solving oriented as has been recommended out of educational efficacy in the WHO Educational Handbook for Health Personnel (Guilbert, 1999). Furthermore the program is markedly project-based learning oriented, possibly enhancing its public health relevancy (Guilbert, 1999; HCRC, 2000) as one could consider looking at the projects 
Table 5. Students' satisfaction monitored through the SWOT technique: most frequently mentioned points in a yearly survey (pooled data of 465 questionnaires corresponding to 166 students) ranked from 1 to 4.

\begin{tabular}{|c|c|}
\hline Successes & Weaknesses \\
\hline 1. Strengthening of professional network & 1. Lack of interaction with the employer \\
\hline 2. Project and community based approach & 2. Program heavily "one-person-oriented" \\
\hline 3. Interactive pedagogy & 3. No common project to the whole student body \\
\hline 4. Acquisition of new public health tools & 4. Difficulties in exploring new topics/tools \\
\hline Opportunities & Threats \\
\hline 1. Students from different professional backgrounds & 1. Time constrains \\
\hline 2. Discussions on new public health challenges & 2. Additional workload \\
\hline 3. Interdisciplinarity & 3. Lack of institutional support \\
\hline 4. Professional carrier improvement & 4. Changing public health competencies over time \\
\hline
\end{tabular}

developed by students of the program and ultimately implemented in their employing institutions or in their respective communities or even contributing to efficient public health workforce, an ever needed "species" as mentioned by the Institute of Medicine (Institute of Medicine of the National Academies, 2003).

Defining learning objectives allowing the acquisition of basic public health competencies through project planning and implementation was a globally appreciated exercise for most students, though often also a somewhat difficult endeavor as has been reported in the literature (Edutechwiki, 2009). For the students it meant actively shaping their education, thus becoming the architect of their training as recommended by educational experts from WHO (Guilbert, 1999) and doing it in a public health perspective, i.e. proposing projects relevant to their community and/or institution. As shown in Table 1 the acquisition of specific public health skills was possible through project planning and implementing, a acquisition mechanism often reported by project learning and learning by doing supporters/experts (Thomas, 2000; Mergendoller \& Thomas, 2003). Yet, in our program the progress in various competencies, as shown in Table 3, was also facilitated through more traditional problem-solving group work, i.e. realizing in class assignments, as the ones shown in Table 2. Such group work also facilitated interaction among students and exchange of experiences, a hallmark of adult learning (Knowles, Holton, \& Swanson, 2015).

From the students' perspective most satisfying elements were the "development of a functioning professional network", the "implementation of public health projects in the community", the "boosting of professional carrier", the "acquisition of specific public health tools", the "increased awareness of the need for life-long learning".

Over time the development of a functioning network became a primary objective of the program for the coordinating staff because of its importance in a public health action perspective. Indeed, functioning networks have been stressed as a key factor for an efficient public health policy (Luke \& Harris, 2007): e.g. network strategies to advance public health for Europe have been proposed (Se- 
menza, Apfle, Rose, \& Giesecke, 2008). Though public health networks have primary been used to control infectious diseases, their importance has been demonstrated in different contexts: diffusion of information and innovations, influence on personal health behaviors, role of social support, influence on organization of the health sector (Valente \& Davis, 1999; Leischow \& Milstein, 2006; Valente, Gallaher, \& Mouttapa, 2004).

In our project centered and problem-based on-job curriculum some major challenges had to be faced by students (and staff):

- A major challenge for most of our students has been time constraints related to supplementary workload due to the program requirements. Indeed, our program is an on-job program and our students are mainly professionals in their late thirties-early forties. This means managing educational objectives and job requirements, family obligations and community involvement. Of course one could also consider that this time management challenge is a specific skill useful for any professional as has been suggested by some authors (Trueman \& Hartley, 1996).

- A second challenge for many students was to acquire new competencies in exploring new public health challenges and new public health tools, because of time constraints or out of commodity, and somehow favored by our individual and project-based educational approach, though our list of public health competencies served as a reassuring/stressing framework. Yet professional competencies required in public health are not a static set in an ever-changing world facing ever-changing health problems (Pruitt \& Epping-Jordan, 2005).

- Another challenge was handling the "interface between educational objectives of the students and professional expectations of the employers": this implies flexibility from the employers and from the employees (our students), ultimately requesting some negotiating skills as well as adapting and transformative learning (Harvey, 2000). However some concrete support from the employer is needed, be it financial or organizational: this definitively strengthens the student-employee's motivation (Schuller, Raffe, \& Clark, 1997).

Some built-in bias might exist in our report. Indeed especially the students' self-reported perceptions of the program might be considered as quite subjective. Yet our observations might well suggest that a community-oriented, project-based, on-job public health program possibly gives students competencies that enable them to implement projects that might ultimately improve the health of the populations they are in charge of. Another limit of our approach is the non-systematic data collection on specific outcomes, though we were able to estimate some community impact due to the project-based approach the program is heavily built on.

\section{Conclusion}

Twenty-five years of a community-oriented and project-based public health training program have strengthened ties between the University and the health authorities, the public health actors as well as triggered many prevention and 
health promotion projects in the communities. Yet it has not triggered a drastic change in the health sector that would have put on top of the agenda disease prevention and health promotion.

\section{References}

Chastonay, P., Durieux-Paillard, S., Guilbert, J. J., Brenner, E., \& Rougemont, A. (1994). A Learner-Centered Curriculum in Public Health at the University of Geneva. Teaching \& Learning in Medicine, 6, 75-85. https://doi.org/10.1080/10401339409539651

Chastonay, P., Guilbert, J. J., \& Rougemont, A. (1992). Les besoins institutionnels en matière de santé publique: Une enquête dans trois cantons romands et au Tessin. Cahiers Médico-Sociaux, 36, 45-53.

Chastonay, P., Papart, J. P., Durieux-Paillard, S., Etter, J. F., Etienne, Y., Barazzoni, F. et al. (1997). Stratégies et outils pédagogiques dans le cadre d'un Diplôme de santé publique. Sozial- und Präventivmedizin, 42, 55-65. https://doi.org/10.1007/BF01299578

CH-EDK. Centre d'Information et de Documentation. Formation Continue (2013). https://systemeeducatif.educa.ch/fr/formation-continue-3

Edutechwiki (2009). Project-Based Learning. http://edutechwiki.unige.ch/en/Project-based_learning

EU Education and Culture DG (2015). Tuning Educational Structures in Europe. Approaches to Teaching, Learning and Assessment in Competences Based Degree Programmes. http://www.unideusto.org/tuningeu/teaching-learning-a-assessment.html

European Commission (2015). The Bologna Process and the European Higher Education Area. http://ec.europa.eu/education/policy/higher-education/bologna-process_en

Guilbert, J. J. (1999). Educational Handbook for Health Personnel. Geneva: WHO.

Habicht, J. P., Victora, C. G., \& Vaughan, J. P. (1999). Evaluation Designs for Adequacy, Plausibility and Probability of Public Health Program. International Journal of Epidemiology, 28, 10-18. https://doi.org/10.1093/ije/28.1.10

Harvey, L. (2000). New Realities: The Relationship between Higher Education and Employment. Tertiary Education and Management, 6, 3-17. https://doi.org/10.1080/13583883.2000.9967007

Health Careers Resource Consortium (HCRC) (2000). Project-Based Learning for Health Careers Pathways. http://californiaeducatorsnetwork.com/reports/Project_Handbook.pdf

HRSA Bureau of Health Professions. Public (2005). Health Workforce Study 2005. http://bhpr.hrsa.gov/healthworkforce/reports/publichealthstudy2005.pdf

Hsieh, H. F., \& Shannon, S. E. (2005). Three Approaches to Qualitative Content Analysis. Qualitative Health Research, 15, 1277-1288. https://doi.org/10.1177/1049732305276687

Institute of Medicine of the National Academies (2003). Who Will Keep the Public Healthy: Educating Public Health Professionals for the 21st Century? https://www.nap.edu/catalog/10542/who-will-keep-the-public-healthy-educating-publi c-health-professionals

Jacobs, J. A., Jones, E., Gabella, B. A., Spring, B., \& Brownson, R. C. (2012). Tools for Implementing an Evidence-Based Approach in Public Health Practice. Preventing Chronic Disease, 9, Article ID: 110324. https://doi.org/10.5888/pcd9.110324

Knowles, M. S., Holton, E. F., \& Swanson, R. A. (2015). The Adult Learner. The Definitive Classic in Adult Education and Human Resource Development (8th ed.). Oxon: Routlege.

Leischow, S. J., \& Milstein, B. (2006). Systems Thinking and Modeling for Public Health 
Practice. American Journal of Public Health, 96, 403-405.

https://doi.org/10.2105/AJPH.2005.082842

Luke, D. A., \& Harris, J. K. (2007). Network Analysis in Public Health: History, Methods and Applications. Annual Review of Public Health, 28, 69-93.

https://doi.org/10.1146/annurev.publhealth.28.021406.144132

Mergendoller, J. R., \& Thomas, J. W. (2003). Managing Project Based Learning: Principles from the Field.

http://www.bie.org/images/uploads/general/f6d0b4a5d9e37c0e0317acb7942d27b0.pdf

Petrakova, A., \& Sadana, R. (2007). Problems and Progress in Public Health Education. Bulletin of $W H O, 85,901-980$.

http://www.who.int/bulletin/volumes/85/12/07-046110/en/

https://doi.org/10.2471/BLT.07.046110

Pruitt, S., \& Epping-Jordan, J. (2005). Preparing the 21st Century Global Healthcare Workforce. BMJ, 330, 637. https://doi.org/10.1136/bmj.330.7492.637

Public Health Foundation (2010). Core Competencies for Public Health Professionals. http://www.phf.org/resourcestools/pages/core_public_health_competencies.aspx

Schuller, T., Raffe, D., \& Clark, I. (1997). Part Time Higher Education and the Student Employer Relationship. Journal of Education and Work, 10, 225-236. https://doi.org/10.1080/1363908970100302

Semenza, J. C., Apfel, F., Rose, T., \& Giesecke, J. (2008). A Network Strategy to Advance Public Health in Europe. European Journal of Public Health, 18, 441-447. https://doi.org/10.1093/eurpub/ckn019

Sorensen, L., \& Vidal, R. V. (1999). Getting an Overview with SWOT. Danish National Research Database, Technical University of Denmark.

http://forskningsbasen.deff.dk/Share.external?sp=See467bad-75fe-4552-82f3-92ad7613 e19a\&sp=Sdtu

Thomas, J. W. (2000). A Review of Research on Project-Based Learning. http://www.bobpearlman.org/BestPractices/PBL_Research.pdf

Trueman, M., \& Hartley, J. (1996). A Comparison between Time-Management Skills and Academic Performance of Mature and Traditional-Entry University Students. Higher Education, 32, 199-215. https://doi.org/10.1007/BF00138396

Valente, T. W., \& Davis, R. L. (1999). Accelerating the Diffusion of Innovations Using Opinion Leaders. The Annals of the American Academy of Political and Social Science, 566, 55-67.

Valente, T. W., Gallaher, P., \& Mouttapa, M. (2004). Using Social Network to Understand and Prevent Substance Use: An Interdisciplinary Perspective. Substance Use \& Misuse, 39, 1685-1712. https://doi.org/10.1081/JA-200033210

WHO (2006). World Health Report 2006-Working Together for Health. http://www.who.int/whr/2006/en/index.html

WHO (2007). International Action Needed to Increase Health Workforce. WHO News Release 2007. http://www.who.int/mediacentre/news/releases/2007/pr05/en/ 
Submit or recommend next manuscript to SCIRP and we will provide best service for you:

Accepting pre-submission inquiries through Email, Facebook, LinkedIn, Twitter, etc. A wide selection of journals (inclusive of 9 subjects, more than 200 journals)

Providing 24-hour high-quality service

User-friendly online submission system

Fair and swift peer-review system

Efficient typesetting and proofreading procedure

Display of the result of downloads and visits, as well as the number of cited articles Maximum dissemination of your research work

Submit your manuscript at: http://papersubmission.scirp.org/

Or contact ce@scirp.org 